\title{
THE JENSEN-GRÜSS INEQUALITY
}

\author{
I. BUDIMIR AND J. PEČARIĆ
}

Abstract. The Jensen-Grüss inequality is proved, that is a converse of Jensen's inequality, related to the well known Grüss inequality.

Mathematics subject classification (2000): 26D15, 26B25.

Key words and phrases: Convex functions, Jensen's inequality, entropy mappings.

\section{REFERENCES}

[1] S. S. DRAGOMIR, A converse of the Jensen inequality for convex mappings of several variables and applications, to appear.

[2] I. Budimir, S. S. DRAGOMIR, AND J. PEČARIĆ, Further reverse results for Jensen's discrete inequality and application in information theory, to appear.

[3] A. M. FInK, A treatise on Grüss' inequality, Analytic and Geometric Inequalities and Applications, Kluwer Academic Publisher (1999), 93-113.

[4] D. ANDRICA AND C. BADEA, Grüss' inequality for positive linear functionals, Periodica Mathematica Hungarica Vol. 19 (2), (1988), 155-167. 